\title{
Do cancioneiro anónimo á lírica culta. Consideracións lingüísticas sobre as cántigas recollidas por Marcial Valladares no Diccionario gallego-castellano (1884)*
}

\author{
Leticia Eirín García \\ Universidade da Coruña
}

\begin{abstract}
Resumo:
Un dos obxectivos deste artigo será a análise do papel desenvolvido pola lírica popular no nacemento da literatura culta en lingua galega ao longo dos tempos, xa que se atopa nas orixes da lírica medieval galego-portuguesa e na renacenza das nosas letras séculos despois, no período do Rexurdimento. Mais o presente traballo tamén incluirá un achegamento á lingua das cántigas tradicionais recollidas por Marcial Valladares e incluídas no seu Diccionario gallego-castellano (1884), dada a relevancia destas pezas como testemuño fundamental da fala popular e medio de expresión do pobo galego.
\end{abstract}

\section{Palabras chave:}

Literatura tradicional galega, lírica medieval galego-portuguesa, lingua literaria culta, cantiga, análise lingüística.

\begin{abstract}
:
One of the aims of this paper will be the analysis of the developed role by popular lyric in the origin of the cultured literature in Galician language throughout times, because it is found at the beginning of the Galician-Portuguese medieval lyric and in the rebirth of our literature centuries after the 'Rexurdimento'. This present work will also include an approach to the language of traditional poems compiled by Marcial Valladares and included in his Diccionario gallego-castellano (1884), due to the relevance of these poems as a fundamental evidence of people's language and Galician folk ordinary way of expression.
\end{abstract}

Key words:

Galician traditional literature, Galician-Portuguese medieval lyric, cultivated literary language, poem, linguistic analysis.

\footnotetext{
* Este traballo foi realizado ao abeiro do Programa de bolsas FPU (Formación de Profesorado
} Universitario) do Ministerio de Educación e Ciencia. 


\section{A lírica popular, elemento subxacente na xénese e renacenza do galego como lingua literaria culta}

De nos determos un instante a reflexionar sobre as particularidades que rodean $o$ nacemento do movemento cultural trobadoresco que tiña como lingua de expresión o galego-portugués, e que se desenvolveu nos reinos cristiáns occidentais da Península Ibérica entre finais do século XII e mediados do século XIV, veriamos como inevitabelmente aparece a sospeita, ou mesmo a probábel certeza, da preexistencia nestes territorios dunha literatura oral e popular que dun ou doutro xeito tería deixado a súa pegada na lírica profana medieval galego-portuguesa, nomeadamente na configuración dun dos seus xéneros canónicos principais, a cantiga de amigo.

Non é a nosa intención formularmos nestas páxinas, e moito menos darmos unha solución, á tan manida cuestión da orixe da lírica trobadoresca galego-portuguesa, que en termos xerais e segundo apunta Tavani (1991: 23), se confunde coa orixe da poesía románica en canto conduce cara a unha raíz trobadoresca común que dirixe a aparición e posterior desenvolvemento da lírica culta en todo o occidente medieval europeo. Porén, no caso galego-portugués atopamos a peculiar circunstancia da posíbel relación dun certo paralelismo entre a cantiga de amigo e as carchas mozárabes, ou dun xeito máis preciso, a posibilidade de estas cancións de muller mozárabes constituíren o principio de que partirían as outras líricas peninsulares. Do noso persoal punto de vista, estamos perante unha hipótese con que discrepamos de maneira global, pois se ben existen certas analoxías entre unha e outra tipoloxía lírica, semellan máis evidentes as diverxencias que hai entre ambas. De por parte, para alén deste tipo de cuestións, e coa finalidade de atinxir unha aproximación ou lectura máis exacta da xénese da poesía medieval galego-portuguesa, deberíase atender a unha maior pluralidade de elementos como a matriz lingüística e sociocultural, ou a algúns dos factores que fican englobados nas diferentes teses existentes sobre este tema e que reciben un índice de aceptación máis elevado por parte dos especialistas.

Tampouco podemos esquecer que a poesía de muller presenta un extenso tratamento en moitas das líricas medievais do ámbito románico, desde as chansons de toile francesas ou certas cantigas sicilianas até os villancicos casteláns, mais non só, xa que tamén existen exemplos dentro da literatura xermánica e mesmo en realidades tan diferentes e arredadas da nosa como poden ser as líricas orientais. Isto é totalmente comprensíbel e normal se temos en conta que as cancións de muller refiren sentimentos e actitudes amorosas que posúen validez universal, de maneira que xulgamos arbitraria a limitación ou redución da poesía peninsular posta en boca de muller a esa suposta orixe mozárabe. 
Mais retomando o asunto dos vestixios da literatura popular na lírica galego-portuguesa medieval, son numerosas as voces que chaman a atención para certos trazos que revelan en maior ou menor medida a presenza do elemento popularizante non só no xénero de amigo, senón tamén no de escarnio e mesmo no de amor, tal e como pon en evidencia xa a comezos do século XX a filóloga alemá Carolina Michaëlis de Vasconcelos no último capítulo da súa edición crítica do Cancioneiro da Ajuda, que precisamente leva por título "Vestíjios de poesia popular galego-portuguesa arcáïca. Sua semelhança com as modernas cantigas do povo. Seu influcso provável na poesia trovadoresca":

Tanto na outra metade do Livro das Donas, que consta de balletas á francesa, como no Cancioneiro de burlas picarescas e de maldizer, em que todos os moldes se misturaram, e mesmo no Cancioneiro de Amor com as suas canções "em maneira de proençal", os trovadores e jograes não se subtrahiram por completo á influencia da lyrica popular. Na facil repetição thematica da mesma ideia em todas as estrophes da mesma composição, e no papel preponderante que tambem ahi tem a menina solteira, ha vestigios do costume $\mathrm{e}$ gosto gallego-português (Vasconcelos 1990: 938).

Con todo, e como é comunmente sabido e (re)coñecido, o xénero que amosa unha maior presenza de elementos folclóricos é o de amigo, especialmente algunhas composicións como as cantigas de romaría, as alvas, as bailadas ou as mariñas, textos estes en que a forma, a temática e o simbolismo da súa linguaxe fican certamente afastados dos moldes máis puramente cortesáns. Deste xeito, do punto de vista formal é habitual a utilización do paralelismo, nalgúns casos combinado co leixa-pren, a rima asoante e a chamada sinonimia estereotipada (do tipo amigo / amado). Canto á simboloxía e aos temas, atópanse frecuentemente símbolos baseados en elementos da natureza referidos ao amor como poden ser, entre outros, o encontro dos amantes á alba no río ou na fonte, o acto de lavar os cabelos ou prendas íntimas, a presenza do cervo ou do vento etc. Estas características son especialmente visíbeis no cancioneiro dalgúns poetas como Pero Meogo, Martin Codax, Meendinho, ou mesmo no do rei e trobador Don Dinís, cuxos textos, a pesar de se definiren en termos xerais por un achegamento aos moldes provenzais máis cultos, contemplan tamén estoutros motivos populares, como proba a seguinte alva [B 569/V 172], onde se dan cita varios dos recursos e símbolos citados:

Levantou s'a velida, levantou s'<aa> alva, e vai lavar camisas eno alto, vai las lavar $<a>$ alva 
Levantou s'a louçana, levantou s'<aa> alva, e vai lavar delgadas eno alto, vai las lavar <a alva $>$

$<$ E > vai lavar camisas; levantou s'<aa> alva; $o$ vento lhas desvia eno alto, vai las lavar $<a>$ alva

E vai lavar delgadas; levantou s'<aa> alva; o vento lhas levava eno alto vai las lavar $<$ a alva $>$

$O$ vento lhas desvia;

levantou s'<aa> alva, meteu s' $<$ a $>$ alva en ira eno alto, vai las lavar $<$ a alva $>$

$O$ vento lhas levava; levantou s'<aa> alva; meteu s'<a> alva en sanha eno alto, vai las lavar $<a$ alva $>1$

Mudando de xénero, e xa dentro das cantigas satíricas, temos de facer referencia á cantiga de vilão, así denominada no capítulo oitavo da Arte de Trovar fragmentaria incluída no Cancioneiro da Biblioteca Nacional onde, a pesar do alto grao de deturpación en que se atopa o manuscrito, pode lerse o seguinte:

Outrossi outras cantigas fazem os trobadores, a que chamam "de vilãos". Estas cantigas $<\dagger>$ sem mao lengua $<$ ge $>$ : nam son per al trobas, porque $<e l>$ as nom escarniom ne $<m$ falam mal $>$ como outras cantigas; pode $<m>$ as fazer de quantos talhos <quiserem> (AT: 44).

\footnotetext{
1 Texto tomado da recente edición das cantigas de amigo realizada por Rip Cohen (2003: 602).
} 
Citamos estas liñas por se trataren de un dos dous únicos testemuños que evidencian a existencia desta modalidade poética, debido a que non se conserva nos manuscritos ningunha cantiga que responda a estas características. A outra proba constitúena as rubricas explicativas que preceden e seguen, respectivamente, a cantiga de Joan de Gaia Vosso pai na rua [B 1433/V 1043], composición en que, segundo manifestan as propias rubricas", o poeta "segue" unha cantiga de vilão reproducindo o seu refrán e incorporándoo tamén como refrán na propia composición aínda que cun sentido diverso, adoptando así un dos modos máis habituais, de entre os tres existentes, de "seguir" outra cantiga:

Diz ũa cantiga de vilão:

"a pee dũa torre,

baila corpo brioso:

vedes o cós, ai, cavaleiro!"

Vosso pai na rua,

ant' a porta sua:

vede-lo cós, ai, cavaleiro!

Ant' a sa pousada,

en saia 'pertada:

vede-lo cós, ai, cavaleiro!

En meio da praça,

en saia de baraça:

vede-lo cós, ai, cavaleiro!

Esta cantiga seguiu Joan de Gaia per aquela de cima de vilãos, que diz o refran: Vede-lo cós, ai, cavaleiro! E feze-a a un vilão que foi alfaiate do bispo Don Domingo Jardo de Lisbõa $[\ldots]^{3}$

Pódese afirmar, case con total certeza, que estas cantigas de vilão posúen unha marca popular que xa se atopa suxerida na súa propia denominación, mais isto non fica aquí, porque tal e como indica Blanco (2000: 38) "debían de ter un amplo público que gustase delas, aínda que fose o menos entendido e refinado e, polo tanto, menosprezado polos trobadores e xograres que tiñan como meta unha obra elevada e "moderna" e un auditorio culto e, a poder ser, xeneroso". Desta maneira, e a pesar de o texto de que parte o escudeiro Joan de Gaia non ter sido conservado nos can-

\footnotetext{
2 Sobre as rubricas, véxase Lagares Díez (2000).

3 Texto tirado da edición de Manuel Rodrigues Lapa (1995: 136).
} 
cioneiros galego-portugueses (seguramente por ese carácter popular da composición que a excluiría dunha compilación de lírica culta), podemos deducir que debía de ser amplamente coñecido na época polo público pertencente ao común do pobo.

Mais para alén da presenza do folclórico nestes casos, non podemos deixar de mencionar o uso que os trobadores galego-portugueses fan do chamado "vervo antigo" ou "vervo aguisado", isto é, ditos ou refráns populares que habitualmente aparecen inseridos no comezo ou no final das cantigas (a modo de fiinda), ou mesmo reiterados como refrán. A súa presenza engade ou dota a composición, como moi ben indica Filgueira Valverde (1990: 18-31), dunha grande expresividade e dun sentido aseverativo, sentencioso ou proverbial, chegando mesmo á consideración de 'cita de autoridade', o summum dos saberes e experiencias populares recollidos ao longo dos tempos. Por outra parte, en ocasións, e tal e como acontece nalgunhas cantigas de amigo (mais non só), áchanse nestes "vervos" antigos certos arcaísmos léxicos do tipo la(s), louçana, irmana etc., vocábulos xa anacrónicos na altura e cuxa inclusión nas cantigas para alén de remitir a unha tradición lírica anterior redundan nunha maior expresividade. É este o caso tamén, por exemplo, dun dos "vervos" antigos que o xenial trobador Joan Garcia de Guilhade reproduce nunha das súas composicións satíricas [B 1502] "Castanhas eixidas, e velhas per souto", e que nas estrofas seguintes aparece reiterado como refrán, mais xa coa substitución do termo arcaico eixidas por saídas.

Tendo presente todos estes aspectos que fomos comentando até ao momento, vemos, aínda que dun xeito moi sintético, como esa primitiva poética de carácter popular existente no occidente peninsular (e probabelmente xa reelaborada nas cortes) ao confluír coa lírica cortesá de orixe basicamente occitana, dá como resultado a aparición dunha das líricas máis sobranceiras da Europa medieval, unha lírica que ten como medio de expresión o galego-portugués, lingua que se erixiu en koiné poética e que foi adoptada por trobadores pertencentes ás diversas cortes peninsulares para as súas creacións. Mais este tempo esplendoroso verá o seu fin a mediados do século XIV, e de aquí en adiante, e durante varios séculos, a lingua galega ficará reducida a un uso oral e excluída de calquera práctica literaria culta.

A pesar do precedente criado polos Ilustrados xa no século XVIII, non será até á centuria seguinte, e ao abeiro do espírito romántico predominante na Europa da época, que comecen a escoitarse as primeiras voces que, á par dunha progresiva concienciación nacional, procuren e reivindiquen a recuperación da cultura tradicional como sinal básico e elemento diferencial da nosa comunidade. En consecuencia, un dos labores realizados neste sentido polas persoas implicadas no que veu a chamarse o Rexurdimento, foi a recolleita da literatura tradicional galega como unha das máximas expresións da identidade do pobo e como avanzo de grande relevancia para a dignificación da lingua. Mais o paso que contribuíu de xeito definitivo neste sentido foi a publicación no ano 1863 dos Cantares gallegos de 
Rosalía de Castro, obra que inicia o período coñecido como 'Rexurdimento pleno', e que logra conciliar nas súas páxinas a tradición lírica do pobo e o xenio literario da autora, elevando así novamente o galego ao estatuto de lingua literaria culta e convertíndose, de por parte, na portavoz dunha comunidade aldraxada durante séculos (Blanco 2000: 85-89).

Mais esta preocupación pola literatura de transmisión anónima non xorde unicamente na Galiza, xa que en terras portuguesas persoeiros da talla de Leite de Vasconcelos, Almeida Garrett, Teófilo Braga ou Carolina Michaëlis de Vasconcelos, tamén baixo a influencia do Romantismo, dedicaron moitas das páxinas dos seus traballos ao estudo do cancioneiro e do romanceiro tradicional, así como á indagación das posíbeis pegadas da poesía popular na lírica galego-portuguesa medieval ou ao vínculo galego-portugués que aínda continuaba (e continúa) a detectarse nas cántigas e romances recollidos nun e outro lado do Miño. É o caso da introdución realizada por Teófilo Braga para o Cancionero popular gallego (1885-1886) de José Pérez Ballesteros ou do xa mencionado capítulo incluído no segundo tomo da edición do Cancioneiro da Ajuda de Carolina Michaëlis de Vasconcelos.

En definitiva, nestas liñas iniciais unicamente tentamos evidenciar moi brevemente a importancia da lírica autóctona na xénese da literatura culta en lingua galega (ou galego-portuguesa) xa na Idade Media, coa simple finalidade de chegarmos a un mellor entendemento do importante labor de recolleita e estudo do cancioneiro anónimo realizado por algunhas das principais personalidades do Rexurdimento galego no século XIX, tal e como veremos a continuación. Así, e antes de nos adentrarmos no estudo lingüístico das preto de trescentas cántigas incluídas no Diccionario gallego-castellano (1884) de Marcial Valladares, e que aparecen a modo de exemplificación dalgunhas das entradas deste, consideramos necesario facer referencia a unha serie de elementos de relevancia para a posterior comprensión das características destas pezas tradicionais.

\section{O papel de Marcial Valladares na cultura galega do Rexurdimento}

A obra de Marcial Valladares Núñez (Vilancosta-Berres-A Estrada, 1821-1903) comprende moi diferentes aspectos, desde o cultivo da poesía e a novela até á gramática, a lexicografía ou o estudo do folclore, mais probabelmente a súa personalidade sexa recoñecida comunmente por ser o autor da primeira novela das letras galegas contemporáneas, Majina ou a filla espúrea (1880).

Colaborou ao longo da súa vida en xornais como La Exposición Compostelana, El Eco de Galicia (La Habana), Galicia, Galicia Humorística, La Revista Popular, O Tío Marcos da Portela, A Monteira, La Ilustración Gallega y Asturiana etc., publicando 
traballos e artigos de diversa índole (literarios, gramaticais, lexicográficos). Tamén formou parte do xurado dos primeiros Xogos Florais, celebrados en Pontevedra no ano 1861, e pouco despois catro das súas composicións poéticas aparecerán recollidas no Álbum de la caridad (1862). Entre as distincións obtidas, cómpre salientarmos que Marcial Valladares é electo en 1884 "socio de mérito" da sociedade coruñesa "El FolkLore Gallego", presidida por Emilia Pardo Bazán, e que nese mesmo ano é nomeado "membro correspondente" da Real Academia Española de la Lengua.

O noso autor inicia nos anos cincuenta o seu labor como gramático e lexicógrafo, tarefas que vai desenvolver ao longo de toda a súa vida. Debemos lembrar ao fío deste asunto que é precisamente neste momento e neste contexto, o Rexurdimento galego do século XIX, cando comezan a xurdir as primeiras voces, nomeadamente a de Rosalía de Castro no prólogo de Cantares gallegos, que poñen de relevo a inexistencia duns estudos lingüísticos galegos que doten a nosa lingua dunha certa sistematicidade e uniformidade (fronte ao dialectalismo, polimorfismo e heterografía por que se caracterizaba), e que por súa vez faciliten a recuperación do galego como lingua literaria. Deste modo, principia a aparición das primeiras gramáticas e dicionarios, que a pesar de escasos e pouco relevantes, teñen a importancia de suporen o comezo dun camiño. Canto ás características dos estudos gramaticais, un dos trazos que os define é a súa moi tardía aparición a respecto doutras nacións e linguas (xa que as primeiras gramáticas das linguas romances datan do século XVI), mais tamén o seu carácter normativo, consecuencia da necesidade de fixación dun modelo lingüístico, e diglósico, debido a que non só están redixidos en español, senón que están feitos en función ou en contraste con esta lingua.

A nosa tradición gramatical está composta polos seguinte volumes: Compendio de gramática gallega-castellana (1864) de Mirás, Gramática gallega (1868) de Saco Arce, El habla gallega. Observaciones y datos sobre su origen y vicisitudes (1868) de Cuveiro Piñol e, por último, os Elementos de gramática gallega de Marcial Valladares, que foi redixida en 1892 mais aparecerá por vez primeira no ano 1970, razón por que non tivo ningún tipo de influencia nos traballos gramaticais posteriores. Estes Elementos teñen unha clara orientación prescritiva e neles alude Valladares (case sempre tomando como modelo de referencia e de corrección o castelán) á súa moi criticada opción ortográfica, ademais de rexeitar a gheada ou construcións perifrásticas tipicamente galegas e abordar algunhas ideas sobre a constitución da nosa lingua literaria. Mais é sen dúbida a gramática de Saco Arce a primeira que podemos considerar como tal dado que se atopa á altura doutros estudos gramaticais da época nos diferentes contextos romances, aspecto que se debe á formación filolóxica con que contaba o seu autor, á diferenza do que acontecía cos demais estudiosos, que carecían destes coñecementos ${ }^{4}$.

\footnotetext{
4 Véxase a este respecto o artigo de Sánchez Rei (2005) sobre a tradición gramatical galega.
} 
É no ano 1884 cando sae á luz, publicado pola Imprenta del Seminario Conciliar de Santiago, o Diccionario gallego-castellano que, como o propio Valladares declara, xa tiña rematado desde 1868 . Este volume contén preto de once mil palabras e presenta a peculiaridade da conxunción da lexicografía coa literatura tradicional, característica que fai del un traballo realmente singular. Para a súa realización partiu Valladares do dicionario de Rodríguez e do de Cuveiro Piñol, así como do glosario incluído na parte final dos Cantares gallegos de Rosalía de Castro, incorporando por súa vez voces extraídas da fala popular e de obras literarias (Vilavedra 1995: 589). De por parte, desde unha perspectiva actual, e tamén no momento da súa aparición, considérase que o dicionario de Marcial Valladares é o mellor dos publicados durante o século XIX, probabelmente pola selección de vocábulos realizada polo seu autor e polos propios criterios de edición (eliminación de fenómenos populares, exclusión do léxico antigo etc.).

Para alén do dicionario de Valladares, tamén son publicados nesta época o de Rodríguez (1863) e o de Cuveiro Piñol (1876), así como a obra de Porto Rey, aparecida en fascículos no semanario Villagarcía-Carril. Periódico Semanal-SatíricoCómico durante o ano 1900, aínda que grande parte da mesma ficou inédita até á súa publicación conxunta no ano 2000. Como vemos, e de xeito análogo ao acontecido cos estudos gramaticais, a tradición lexicográfica vén marcada por unha serodia aparición, un escaso rigor científico e unha clara concepción diglósica dada polo facto de todos eles seren dicionarios galego-castelán. Outra característica común é o seu carácter compilativo en detrimento do selectivo, isto é, concédeselle unha maior importancia ao número de entradas que á súa escolma ou selección.

Voltándomos ao labor realizado por Marcial Valladares, e froito do seu interese polo cancioneiro tradicional temos de destacar algunhas obras onde inclúe romances, cántigas e contos de transmisión oral, como o Cantigueiro popular, rematado no ano 1867 mais publicado por vez primeira pola Real Academia Galega xa en pleno século XX (1970), e o Novo apéndice ao cantigueiro popular, datado en 1887. Para alén destes dous traballos, tamén temos de citar dentro deste labor de compilación as case trescentas cántigas inseridas no Diccionario gallego-castellano, algunhas delas procedentes do Cantigueiro popular. Este interese pola literatura tradicional levouno mesmo a colaborar con Antonio Machado y Álvarez na recollida de todas estas composicións anónimas.

Probabelmente sexa a faceta de Marcial Valladares como poeta a menos coñecida, a pesar da súa manifesta facilidade para a versificación e a pesar tamén de ter comezado a publicar as súas composicións en xornais e revistas xa nos anos corenta. Con todo, non será até o ano 2003 cando estes poemas, de carácter maioritariamente costumista e sentimental, sexan reunidos por Fernández Salgado nun volume baixo o título de Poesía. 
Por último, e en vista desta versatilidade creativa, temos de nos referir ao seu papel como narrador e autor da que é a primeira novela das nosas letras, Majina ou a filla espúrea, obra de moldes folletinescos que apareceu por entregas en La Ilustración Gallega y Asturiana en 1880, coñecido como o "annus mirabilis" da nosa literatura por ser o ano en que saen tamén á luz as Follas Novas de Rosalía de Castro, os Aires da miña terra de Manuel Curros Enríquez e as Saudades gallegas de Valentín Lamas Carvajal. Probabelmente o que máis chama a atención na citada novela, para alén do evidente esforzo realizado polo autor para a consecución dunha norma literaria culta, é a fronteira diglósica que se estabelece entre os personaxes, pois as clases altas (aristocracia e burguesía) falan castelán, as baixas (labregos) exprésanse en galego e os desclasados (criadas e serventes) empregan o castrapo. Esta situación leva a Valladares a pór en boca de Majina, de orixe burguesa mais que fora criada entre labregos, palabras en castelán (Freixeiro Mato / Sánchez Rei / Sanmartín Rei 2005: 56-57).

\title{
2. A literatura tradicional galega
}

Antes de máis, e aínda que xa tratamos este tema en páxinas precedentes, consideramos necesario realizar unhas pequenas observacións sobre o propio concepto de literatura tradicional ${ }^{5}$. Neste sentido, e segundo indica Domingo Blanco:

\begin{abstract}
Vénse entendendo por "literatura popular de tradición oral" ou, simplemente, "literatura popular" un conxunto heteroxéneo de formas e xéneros de arte verbal usados, transmitidos e conservados oralmente polo pobo, entendido este como as clases sociais que, nunha sociedade complexa social e culturalmente, participan menos da cultura canónica ou dominante. En Galicia, onde este sector social coincidiu historicamente coa poboación -analfabeta na súa inmensa maioría- das áreas rurais e en boa parte tamén das urbanas, esta literatura reviste unha considerable importancia, tanto pola abundancia da súa producción coma por ter conservado vivo ata hoxe un variado repertorio de grande interese histórico, etnolóxico e, mesmo, artístico. Sen embargo, o seu recoñecemento como valor cultural supuxo un longo e dificultoso proceso que aínda hoxe non está definitivamente consumado (Blanco 1997: 56).
\end{abstract}

Deste modo, a literatura tradicional por ser unha forma de folclore posúe unha serie de características propias que a diferencia ou pon en confronto coa chamada literatura "culta" (Blanco 2000: 17). En primeiro lugar, trátase dunha literatura de transmisión oral (cantada ou recitada) que se difunde de xeración en xeración. Outro aspecto é a súa variación ou mutabilidade no que á forma se refire, de maneira que un texto

5 Resultan moi clarificadores e de grande utilidade os traballos de Domingo Blanco (1997 e 2000) sobre a literatura popular galega e o labor realizado neste sentido por Marcial Valladares. 
pode chegar a ter moi diversas variantes debido ao seu carácter oral. En terceiro lugar, este tipo de composicións, que habitualmente son anónimas, precisan da aceptación da colectividade que a emprega, que pode ser unha comunidade de tipo local ou sectorial (por exemplo, as cántigas das costureiras). Por último, temos o que probabelmente é o trazo máis importante da literatura folclórica, o facto de ter unha funcionalidade concreta que é coñecida e aceptada polo pobo, isto é, debe integrarse no conxunto das funcións comunitarias: ensinar, soportar o traballo, galantear, mofarse etc.

Canto á historia da nosa literatura tradicional, e para alén do xa indicado a respecto da Idade Media, no período coñecido como Séculos Escuros temos constancia da existencia e transmisión desta literatura, aínda a pesar do silencio en que se viu sumida a literatura culta. Foron dous dos ilustrados do século XVIII, Sarmiento e Sobreira, os encargados de recolleren e estudaren estas cántigas, contos e refráns procedentes da oralidade e incluílos nos seus traballos sobre lexicoloxía. Desta maneira, a literatura oral pasa xa a desenvolver unha pequena función dentro da cultura escrita (Blanco 1997: 58).

No século XIX foi a prensa o medio que contribuíu dunha maneira máis clara para a difusión do cancioneiro anónimo, e, así, isto permitiu e coadxuvou a que se fose estendendo entre as elites cultas a idea de Galiza como comunidade diferenciada. No medio deste auxe, foron xurdindo publicacións do tipo de Galicia. Revista Universal de este Reino, dirixida por Antonio de la Iglesia, onde estudiosos e interesados na materia, como José López de la Vega, irían incluíndo nas súas páxinas cántigas e refráns. Mais, como xa indicamos, a valorización definitiva viría despois da aparición de Cantares gallegos de Rosalía de Castro no ano 1863, e da publicación do primeiro tomo da Historia de Galicia de Murguía, obras en que por vez primeira a literatura tradicional ocupaba un espazo relevante como parte da cultura galega. Nos anos que seguen á aparición destes volumes principian a se realizar recollidas e estudos sobre a nosa literatura de transmisión oral, especialmente sobre as cántigas, da man de persoeiros como Antonio de la Iglesia, o propio Marcial Valladares, Manuel Murguía, José Casal, José Pérez Ballesteros, Manuel Milà y Fontanals, Juan Antonio Saco Arce ou Luís Tobío. De entre todos estes, o traballo máis amplo foi o realizado por Pérez Ballesteros, que pasou a ser considerado o cancioneiro tradicional galego por excelencia (Blanco 1997: 60).

Os estudos sobre a literatura anónima galega e a súa sistematización ficaron, non obstante, estabelecidos por Murguía na obra antes citada, aínda que, de xeito paralelo ao acontecido cos estudos gramaticais, a colección de cántigas máis importante e rigorosa lla debemos a Saco Arce, que realizou tamén un completo estudo sobre os xéneros, escenarios e modos de produción. Anos despois, en 1877, e grazas ao prestixio acadado pola súa ampla experiencia investigadora, Milà logrou difundir o noso folclore a nivel europeo a través da revista Romania, ao incluír no seu artigo titulado "De la poesía gallega" non só un estudo caracterizador da 
literatura tradicional, senón tamén unha colección de case 150 textos (Freixeiro Mato / Sánchez Rei / Sanmartín Rei 2005: 91).

Xa para finalizarmos este percurso, non debemos esquecer o entusiasmo que Antonio Machado y Álvarez puxo na recolleita da tradición literaria anónima da Galiza, entusiasmo que se estendeu a outras personalidades da época, e que remataría coa creación no ano 1884, e a iniciativa do propio Machado, da sociedade "El Folk-Lore Gallego", que desenvolveu ao longo dos seus anos de actividade un importante labor de difusión.

\subsection{Marcial Valladares: recolleita e estudo de cántigas tradicionais}

Como é comunmente sabido, Marcial Valladares Núñez escribiu a primeira novela das nosas letras contemporáneas, mais tamén foi un dos primeiros en se dedicar á recollida de cántigas tradicionais, xa que comezou este labor a comezos da década de sesenta do século XIX. Todo parece indicar, segundo afirma Domingo Blanco (2000: 96), que foi el mesmo quen recolleu as citadas pezas na súa terra natal, na Ulla, mais estas non saíron á luz até unha época moi posterior. De todos os xeitos, si facilitou parte das súas recolleitas a outras personalidades interesadas no tema como Murguía, que publicou os doce tercetos que compoñen a Ruada na súa Historia de Galicia, e tamén forneceu textos a Saco Arce, Rodríguez Marín, que reproduciu vintecinco destas pezas na obra Cantos populares españoles, ou a Machado y Álvarez, que as incluíu no tomo IV da Biblioteca de las Tradiciones populares españolas que el mesmo dirixía. Deste modo, a recolleita realizada por Valladares foi unha das máis estendidas da altura.

O Cantigueiro popular (Cántigas da Ulla) está datado no ano 1867, aínda que permaneceu inédito até 1970, e nel inclúense cento noventa cántigas, o que constitúe a compilación máis ampla das realizadas até ao momento. Ao ano seguinte, en 1868, xa tiña Valladares terminado o Diccionario gallego-castellano (que será publicado no ano 1884), onde aparecen duascentas setenta e unha poesías tradicionais coa finalidade de exemplificaren algunhas das entradas do mesmo, procedemento que xa tiñan empregado no século XVIII Sarmiento, Sobreira ou o autor descoñecido das Vozes gallegas. Aínda en 1887 foi elaborado o Novo apéndice ao Cantigueiro popular, que tamén permanecerá inédito durante case setenta anos até que en 1956 Bouza Brey decide dalo ao prelo.

Para alén do interese de Valladares pola literatura tradicional, temos de acrecentar o coñecemento que este tiña do noso folclore no seu conxunto, pois tamén transcribiu a música dalgunhas das cántigas recollidas, o que dá unha idea do concepto global que posuía deste xénero como unión da música e da literatura. Neste sentido, tamén ve con pesimismo a pervivencia do xénero dada a ameaza que está a supor na altura a introdución das coplas casteláns (Blanco 2000: 97-98). 
Un último punto a que desexamos facer referencia neste apartado é a moralidade que adopta para a selección das pezas incluídas nos seus diversos traballos, xa que como indica no prólogo ao seu dicionario $(D G C \mathrm{~V})$, publica "cántigas que a la moral no ofendan", isto é, omite estrofas de carácter satírico ou burlesco (referidas a cregos, vellas etc.), temática moi habitual neste tipo de literatura. Esta actitude pode deberse á educación de que foi obxecto e á súa propia extracción social, a fidalguía rural, mais o que si fica claro, polo menos desde unha perspectiva actual, é que este criterio restou e resta elementos ao coñecemento da nosa literatura de transmisión anónima. Con todo, non se trata do único compilador que na altura decide prescindir de certos cantares por esta mesma razón, pois o presbítero Juan Antonio Saco Arce na "Introducción" á Literatura popular de Galicia. Colección de coplas, villancicos, dialogos, romances, cuentos y refranes gallegos, observa a propósito da temática das pezas que "No faltan algunas de sabor marcadamente impio, que hemos rechazado de esta colección, como también las que directa o indirectamente lastiman el pudor. Creemos que lo inmoral, lejos de merecer perpetuarse por el arte de Guttemberg, debe condenarse a eterno olvido" (1987: 38-39).

\section{Análise lingüística das cántigas incluídas no Diccionario gallego-castellano (1884)}

Antes de máis, queremos deixar claro que a nosa análise estará artellada por volta de tres grandes aspectos, gráfico-fónico, morfosintáctico e léxico, mais este estudo cinxirase a aqueles elementos ou fenómenos que dun xeito máis evidente se manifesten como propios deste tipo de lingua popular, como é obvio dada a súa pertenza á literatura folclórica. Así, o primeiro e o último dos aspectos mencionados terán especial relevancia, pois é neles onde dun modo máis evidente se producen os fenómenos propios da fala popular. Mais tamén é certo que mesmo a produción digamos "culta" deste século XIX se caracteriza igualmente por esa tendencia a imitar os trazos linguiísticos do pobo e pola procura dun diferencialismo a respecto do español e da españolización que en termos xerais se estaba a producir na fala habitual. Polo tanto, podemos case afirmar que ambos os tipos de literatura amosan unha inclinación cara ao popular, aínda que no caso das cántigas que analizaremos este elemento sexa moito máis claro por se tratar de pezas recollidas directamente do pobo.

\subsection{Aspectos gráfico-fónicos}

A comezar polos aspectos gráficos, temos de nos deter na cuestión do modelo ortográfico e a controversia entre etimoloxistas e non etimoloxistas, pois no caso galego a ausencia de institucións que velasen polo idioma e a inexistencia dun poder político propio foron os causantes de que se chegase ao século XX sen ter 
resolvidos os problemas da grafía. Os escritores que no século XIX retoman a escrita literaria do galego fano empregando as grafías do castelán, lingua en que foran educados, mais o principal problema era a representación dos fonemas que non existían ou non eran coincidentes con esoutro idioma (Freixeiro Mato / Sánchez Rei / Sanmartín Rei 2005: 82). Deste modo, e entre moitos outros aspectos, a principal dificultade foi a representación do fonema fricativo prepalatal xordo / /, que dividirá os escritores en etimoloxistas, partidarios do emprego de $<\mathrm{g}\rangle+\langle\mathrm{e}\rangle /<\mathrm{i}\rangle,\langle\mathrm{j}\rangle$ ou $\langle\mathrm{x}>$ de acordo coa etimoloxía, e antietimoloxistas, que propoñen o uso sistemático do $<\mathrm{x}>$, opción que suporá unha ruptura a respecto das restantes linguas romances, nomeadamente do portugués. Porén, esta é unha polémica que continuará acesa ao longo de todo o Rexurdimento e que mesmo chegará aos nosos días.

$\mathrm{Na}$ opción tomada polos escritores etimoloxistas e polos que se amosan partidarios dunha aproximación ao portugués, supomos que tivo de influír, entre outros puntos, o coñecemento da lírica medieval galego-portuguesa, feito que na Galiza tivo lugar nos últimos anos do século XIX grazas á antoloxía de textos medievais que Antonio de la Iglesia inclúe en El Idioma Gallego (1886), tirados estes da edición que o portugués Teófilo Braga fixera no ano 1878 do Cancioneiro da Vaticana ${ }^{6}$. Así, e de aquí en adiante, os nosos escritores disporán dun modelo de lingua medieval descoñecido até este momento.

Mais non podemos deixar de facer referencia explícita á opción de Valladares no que a esta polémica ortográfica se refire, xa que a súa postura é bastante peculiar, tal e como explica Mariño:

A postura que Hermida denomina "castelanista" foi a defendida por Marcial Valladares, que avanzou a súa proposta en 1888 para acabar de concretala en 1892. Este autor suxería que se podería empregar $<\mathrm{g}>$ naquelas voces que en castelán levasen $\langle\mathrm{g}\rangle,\langle\mathrm{j}\rangle$ nas que en castelán tivesen $\langle\mathrm{j}\rangle \mathrm{e}\langle\mathrm{x}\rangle$ só nos casos dubidosos e nos vocábulos que contasen cun correlato castelán con $\langle\mathrm{s}\rangle$. Quere isto dicir que, atendendo á proposta de Valladares, debería escribirse juizo, gente, xeito (por ser caso dubidoso) e xastre (por ter un correlato con $<\mathrm{s}>$ en castelán). Contra isto, nun breve artigo inédito datado en 1896 Valladares elaborou unha proposta netamente foneticista [...] non é doado esclarece-las razóns que puideron mover a Marcial Valladares a este cambio de opinión, pero polo menos pódese dicir que no seu ánimo debeu de pesa-la lectura duns artigos de Jimeno Agius publicados en 1896 en que este autor defendía posicións foneticistas a propósito da polémica ortográfica do castelán (Mariño 1999: 463).

\footnotetext{
6 Véxase a este respecto a obra de Teresa López (1991), e en especial o capítulo dedicado a Antonio de
} la Iglesia e El Idioma Gallego. 
De todos os modos, a publicación do dicionario de Valladares en que se inclúen as cántigas é anterior á súa proposta "castelanista", polo que o modelo gráfico que aquí atopamos é o etimoloxista, opción por que optaban maioritariamente aqueles autores que posuían unha maior preparación académica, aínda que tampouco é estraño atopar algunhas incoherencias en exemplos como este:

Deijei a tüa convèrsa,

s'eu a deijei, non me pesa.

$(D G C 131)$

Outro aspecto gráfico que suscitou abundante polémica no século XIX (e que chegou até aos nosos días) foi o uso de $a o$ o ó para a representación da contracción da preposición $a$ e o artigo masculino. Aquí óptase por ó, que é a opción máis empregada na época, probabelmente porque resulta máis indicativa da crase que se produce na fala:

Periñas me dan, ò almorzo;

ò jantar, peras me dan

$(D G C 21)$

Tamén debemos chamar a atención a respecto dos intentos realizados polos nosos escritores para dalgún xeito representaren a distinción fonolóxica entre vogais de grao medio aberto e fechadas, pois tiñan conciencia clara da importancia deste punto, mais os ensaios realizados a este respecto dan como resultado textos inzados de acentos que fican recargados e mesmo poden chegar a levar a confusión. No caso concreto de Valladares e destas cántigas, achamos acentos gráficos graves (que marcan as vogais medias abertas) e agudos (que marcan a tonicidade ou a fechazón das vogais):

\section{Gobèrna tí, gobèrne él, todos quèren gobernar. Ou o goberno tèn mèl, ou non m'o sei espricar.}

(DGC 286)

No que a trazos gráficos se refire, e para alén do xa indicado, queremos unicamente engadir que os testemuños con que contamos indican que o modelo gráfico empregado é o do castelán, como é normal se temos en conta que esta é a lingua en que todos os nosos escritores foran educados. Isto detéctase especialmente nos usos de $<\mathrm{h}>$ ou na distribución entre $<\mathrm{b}>$ e $<\mathrm{v}>$ : 
Os teus becerriños oito

deija que meu hirman marzo

hách'os de volver en catro.

(DGC 245)

\section{Hisca d'ahi, \\ galiña maldita}

(DGC 323)

Xa entrando nos aspectos fónicos, centrarémonos en primeiro lugar no vocalismo átono, por ser o que presenta unha maior inestabilidade e variación debido á alteración do timbre orixinario das vogais e á adición ou supresión de fonemas vocálicos, o que motiva a aparición dos popularismos na lingua oral. Así, achamos nestas cántigas algún caso que afecta o vocalismo pretónico, como a adición dun $a$ protético, fenómeno que actúa especialmente cos verbos da primeira conxugación, tal e como acontece neste caso:

e arreparei que non tiña

tabaco, papel, nin lume.

(DGC 357)

Mais tamén é habitual na lingua decimonónica o fenómeno contrario, a aférese, e nestas cántigas encontramos un caso especial, a perda da sílaba inicial do pronome posesivo miña na expresión de carácter afectivo ña nai ou ña madre, aquí aliás grafado xunto probabelmente por influencia da súa pronuncia habitual:

\section{Namadre, como son sola, quèr qu'ande sèmpre de gala}

(DGC 407)

Os procesos de asimilación e disimilación son tamén moi comúns na lingua popular, dando orixe á aparición de numerosos popularismos que mesmo pasarán á literatura culta, pode que por desexo de reflectir a fala do pobo ou por simple afán diferencialista. Nas duascentas setenta e unha cántigas que estamos a analizar atopamos o seguinte caso de asimilación dun modo recorrente:

\section{Custureira finiquita}

(DGC 135) 


\section{Custureira bonita}

(DGC 377)

Canto á disimilación, afecta especialmente, como vemos, a vogal pretónica:

S'o casar fora d'un dia, ou d'un ano tan siquèra

$(D G C 157)$

e cinco amores tamèn par'escolle-l-o millor.

$(D G C 333)$

A síncope é un fenómeno que xa funcionaba mesmo no latín vulgar e que ten que ver coa economía lingüística (Ferreiro 1999: 204-205). Normalmente relaciónase coa fala popular, e dase especialmente en posición pretónica nos grupos de oclusiva + vogal átona + líquida:

Fago cangallas pra os pòrcos

e tarambollos pra os cans.

$(D G C 101)$

Catuja vai n'o mercado

con zreixas para vender.

$(D G C 421)$

Pasando ao vocalismo postónico, practicamente non achamos nas cántigas fenómenos representativos, xa que unicamente merece algún comentario a apócope do substantivo casa (en cas), proceso que xa se producía na lingua medieval, tal e como reflite este verso tirado dunha das cantigas de escarnio de Don Dinís [B 1538] andand' aqui en cas d'el-Rei, en canto nas pezas tradicionais se presentan exemplos deste tipo:

vai por él á cas meu pai

$(D G C$ 105)

hisca d'ahi

pra cas de tua dòna.

(DGC 323) 
Por outra banda, no que ao consonantismo se refire, queremos facer especial mención a un fenómeno como a gheada, rexeitada en xeral polos autores do XIX e de modo moi especial polo propio Marcial Valladares, a pesar de este pertencer a unha zona gheadófona. É con case total certeza por esta razón por que a gheada non está representada nas cántigas anónimas que estamos a analizar, aínda que o facto de estas reflectiren a fala popular debía ser unha razón máis que suficiente para Valladares a transcribir nestes textos. Porén, as seguintes palabras do noso compilador poden darnos unha explicación a este respecto:

Las geadas son un defecto de la gente idiota; consisten en hacer fuerte la $g$ suave, como en gaita, guerra, guinda, gozo, gusto; y, siendo un defecto, un abuso de simple pronunicacion, lo mismo que el decir berse, Visente, senteo, siudá, etc., por berce, Vicente, centeo, ciudá; y nabisa, sapato, sarrapicar, soco, etc., por nabiza, zapato, zarrapicar, zoco, etc., en ninguna gramática, en ningun vocabulario, pueden hallar cabida ( $D G C$ VI).

O que realmente chama a atención é que nestas liñas pertencentes ao prólogo do seu dicionario, e tamén na súa gramática, Marcial Valladares condene o seseo explosivo ou total, en canto admite sen problemas o seseo implosivo, que deste xeito reproduce non só nas súas obras de creación literaria, senón tamén nas cántigas que compila:

As tüas festas, rapas,

non che me son nada böas

$(D G C 10)$

A raís d'o tojo verde

è mòi dura d'arrincar.

(DGC 553)

Outro fenómeno fonético moi presente na lingua decimonónica a que queremos facer referencia é a variabilidade locacional de $r$ e a confusión e troca entre as líquidas $r$ e $l$, seguindo unha tendencia habitual na lingua galega que chega mesmo á actualidade:

D'esta fontiña à beira froleada

sentado à sombra d'un choron estou

$(D G C 155)$

As escrouchiñas d'o millo

non fan porveito á ninguèn.

$(D G C 215)$ 
Dis que teño mòitas conchas,

cando non son pelegrino.

$(D G C 441)$

Como último punto dentro deste apartado fónico-gráfico, e en palabras de Freixeiro Mato (2003: 90) "os fenómenos de fonética sintáctica producidos por encontro de dúas vogais na cadea falada son especialmente significativos no galego pola súa secular condición de lingua oral". Deste modo, vemos como no século XIX aínda se continúa a marcar con apóstrofo a elisión vocálica en certas contraccións a pesar de estas seren sistemáticas tanto na oralidade como na escrita:

Dàme d'a pera que còmes;

d'a mazan, un anaquiño;

d'a tua boquiña, unha fala;

d'o corazon, un cariño.

$(D G C 27)$

Mais tamén despois de palabras terminadas en -s o artigo, por fonética sintáctica, tende a presentar variantes alomórficas que poden aparecer representadas de moi diversos xeitos, aínda que Marcial Valladares opta sistematicamente pola seguinte opción:

Non botes tanto por èla,

qu'anque tè-l-a casa grande,

paga-l-a renda por te-l-a.

(DGC 496)

\subsection{Aspectos morfosintácticos}

Un trazo característico da literatura de transmisión oral é a inclusión de antropónimos, de nomes substantivos propios que, de por parte, tenden a se repetir dunha cántiga para outra. Son especialmente recorrentes:

Antoniño, meu Anton

$(D G C 32)$

Se deijo por Pedro á Jan,

(DGC 35)

Domingos è o meu amor,

á Domingos hèi d'amar

(DGC 185) 
Afire-o, Manuel, afire-o

(DGC 388)

Debemos notar tamén como na poesía anónima abundan os substantivos concretos que fan referencia á realidade próxima e circundante como as árbores froiteiras, paxaros, instrumentos musicais empregados nas festas, comida, prendas de vestir etc., en canto que os abstractos rara vez aparecen, e cando isto acontece é normalmente para se referir a sentimentos ou a aspectos relacionados coa relixión:

con ferreñas e pandeiro

$(D G C 250)$

A mazan que ti me dèche non a comin nin a dei; lèvö-a n'a faltriqueira, por che non perde-l-a lei.

(DGC 373)

Non che teño medo, moucho, moucho, non che teño medo.

(DGC 395-396)

Pereiriña de Donguindo,

heiche de dar un avalo

e, se non solta-l-as peras,

lògo ch'arrimo o machado.

$(D G C 444)$

Canto aos pronomes persoais, a literatura tradicional caracterízase tamén pola abundante presenza de dativos de solidariedade que refliten a espontaneidade e afectividade da fala popular e cotiá:

que vai o meu amo fòra

e hacheme de da-l-as queijas.

(DGC 288)

Especial alusión merecen os pronomes demostrativos, nomeadamente aquel e aquela, que poden ser usados como substantivos de carácter indefinido con diversos significados segundo o contexto (Freixeiro Mato / Sánchez Rei / Sanmartín Rei 
2005: 365-369). Este é un proceso que xa vén de antigo e cuxa xénese se debe seguramente á sucesiva perda de valores e progresivo esmorecemento (entre fins do século XVIII e comezos do século XIX) do demostrativo reforzado aqueste / aquesta, valores que recollerían aquel e aquela coadxuvados probabelmente pola proximidade fonética entre ambos. A seguir reproducimos algúns dos exemplos que aparecen nas cántigas:

\section{Pedriño tèn cèrto aquel \\ que mòita gracia me fai.}

(DGC 35)

quèro mullèr solteiriña

e sin aquèla ningunha.

(DGC 35)

Resulta cando menos curiosa a definición que Valladares oferece destes vocábulos no Diccionario gallego-castellano, pois indica o seguinte tanto de aquel como de aquela: "Defecto; imperfección; avería; maleamiento, ó al contrario" (DCG 35). Neste mesmo sentido, temos tamén o caso de aqueloutriño, vocábulo composto polo demostrativo máis o pronome identificador, que por súa vez sufre un proceso de derivación apreciativa (co sufixo -iño); esta palabra, tal e como acontece coas anteriores, presenta unha polivalencia de significados en función do contexto. Mais en moitas ocasións nas pezas tradicionais aqueloutriño vén a significar "meu mociño", tal e como indica o propio Valladares na tradución que realiza deste vocábulo: "Diminutivo de aquel outro.= Mocito" (DGC 36), sentido que tamén recolle Pérez Ballesteros no seu Cancioneiro popular gallego (1979: 46) a propósito da mesma cántiga:

Dime tí, aqueloutriño,

en que modo ch'agradei.

(DGC 36)

Aínda dentro do apartado pronominal, é relativamente frecuente na lingua e nos textos decimonónicos a presenza do pronome ordinal como parte do vocábulo composto que designa, ao xeito tradicional e cristián, os días da semana. No exemplo que temos a seguir, vemos como o ordinal aparece baixo a variante corta:

Adios, martes d'entroido,

còrtafèira de ceniza

(DGC 134) 
Canto ao verbo, resulta especialmente chamativa por recorrente a grande abundancia de exemplos nos nosos cantares en que o futuro é expresado a través de perífrases de futuridade. Isto semella algo habitual a termos en conta que a orixe histórica deste tempo verbal se acha precisamente nunha perífrase latina conformada polo presente do verbo haber e o infinitivo do verbo en cuestión:

Farruco meu ha de ser, que o criei de pequeniño e algunha lei m'ha de ter.

(DGC 243)

$O$ cariño que che teño e mai-l-o que ch'hei de ter caben n'a folla d'un fènto e ha de quedar sin hencher.

(DGC 248)

Por outra parte, e a pesar de se tratar dun tempo característico do sistema lingüístico galego-portugués, son poucos os casos de futuro de subxuntivo que atopamos nestas pezas. Porén, e aínda que na actualidade esta forma verbal diminuíu considerabelmente os seus usos, aparece recollida nas gramáticas e nos textos literarios decimonónicos con total normalidade (Freixeiro Mato / Sánchez Rei / Sanmartín Rei 2005: 484-491).

\section{Onde vires mòito fume}

non te vayas á quentar

(DGC 393)

\subsection{Aspectos do léxico}

De xeito análogo ao xa comentado a respecto das características fónicas, dous son os factores principais que determinan a situación do léxico galego na lingua decimonónica: os fenómenos de variacionismo interno, isto é, dialectalismos, popularismos, arcaísmos etc., e por outra parte, aqueles fenómenos que veñen dados por influencias alleas ou externas á nosa lingua, e que son os españolismos e os pseudogaleguismos (Sánchez Rei 2003: 113).

A comezar polos dialectalismos, nestas cántigas atopamos como é obvio léxico pertencente ao bloque occidental, xa que foron recollidas na Ulla. Así temos por exemplo raposa (fronte a solucións orientais como golpe ou volpe), rula (fronte a 
rola), nai (fronte a mai), a forma harmonizada meniña ou meniño (fronte a vocábulos centro-orientais do tipo pícaro, cativo) etc.

a ladra de tüa nai

meteum'un pau por un ollo.

(DGC 250)

Meniña, miña meniña

(DGC 364)

¡Canta rula, canta rula,

alá se dò n'aquel souto...!

(DGC 509)

Alá vai, ve-l-a alá vai,

a raposa po-l-o prado.

(DGC 576)

Algo que chama especialmente a atención é a convivencia das terminacións -án e ao (procedentes do latino -ANU), cando o habitual na Ulla é a segunda das solucións:

O forno de miña sògra

botaba silvas n'o vrau.

(DGC 72)

deija que meu hirman marzo

hách'os de volver en catro.

$(D G C 245)$

Tamén conviven nas pezas que estamos a analizar os vocábulos castiro e castiñeiro, árbore que foi fundamental na economía e alimentación galega precisamente até o século XIX. Na lingua literaria decimonónica semella máis frecuente a primeira das formas, mais na colección realizada por Valladares a casuística relativa a castiñeiro é maior (Sánchez Rei 2003: 118):

N'aquela banda d'o rio tèn meu pai un castiñeiro

$(D G C 401)$ 
Pasándomos aos popularismos, queremos deternos no emprego do sufixo apreciativo -iño, especialmente recorrente e rendíbel neste caso por estarmos a estudar cántigas tiradas directamente da oralidade onde o emprego deste sufixo é moi común, e mesmo se ten chegado a converter nun signo identificador da nosa lingua e do conxunto de persoas que a falan. Aliás, posúe moi diversos matices e o seu valor pode ir desde o puramente diminuidor, sobre todo aplicado a substantivos, ao poderativo, intensificador, afectivo etc., dependendo do contexto ou da intencionalidade da persoa que o estiver a empregar:

Fun á San Cibran de longe e vin po-l-o de prètiño

\section{(DGC 516)}

\section{Cría ti ò teu filliño;}

dalle d'a tüa tetiña,

que n'hai leite, nin cariño

com'o d'a propia naiciña.

(DGC 550)

Un dos substantivos que máis variantes populares vai chegar a ter é o nome de Satanás: demo, diaño, diacho etc. A causa desta variabilidade seguramente sexa debida ao xogo eufemístico, ao tabú existente para denominar este ser con connotacións negativas no imaxinario e crenzas populares:

Ou tè-l-o diaño, meniña, ou mal me quères, rapaza.

(DGC 182)

Por outra parte, os rexistros populares de lingua facilitan a creación de palabras mediante a composición e a onomatopea (Freixeiro Mato / Sánchez Rei / Sanmartín Rei 2005: 673-674), como vemos nos seguintes exemplos:

Ti ¿qué fas, Férvellasberzas?

(DGC 250)

e chòro o meu a-ia-iai.

(DGC 14)

empeza por ta-ra-ri-ra;

e sigue por ta-ta-ta-ta.

(DGC 542) 
Do punto de vista das variacións externas á lingua a que antes xa aludíamos, desexamos facer unha breve mención aos españolismos, cuxa penetración non foi idéntica en todo o territorio galego, senón que variou segundo as áreas ou comarcas ${ }^{7}$. Neste sentido, e en relación á comarca da Estrada, Valladares indica que na década de noventa do século XIX xa non se empregaban certas palabras galegas que, en consencuencia, eran substituídas pola correspondente voz española:

en nuestro país del Ulla, nadie, ó casi nadie, dice ya alcipreste, arámio, Bièito, cabalèiro, calivèra, candelèiro, doce, enveja, fogo, fròita, habanèiro, igreja, ò ireja, sabán, segredo, sino, ciprès, alambre, Benito, caballero, calavera, candelero, dulce, envidia, fuego, fruta, habanero, iglesia, sábana, secreto (Valladares 1970: 21).

Finalmente, este fenómeno tamén afectou certos vocábulos relacionados con aspectos da vida especialmente españolizados como a igrexa:

Adios, martes d'entroido, còrtafèira de ceniza

(DGC 134)

Adios, campía d'a Ulla:

as còstas che vou virando.

A miña marcha hoj'è cèrta,

a vòlta, sabe Dios cando.

(DGC 586)

\section{Conclusións}

Foi a nosa intención estabelecermos nestas páxinas unha ponte de unión entre períodos tan afastados no tempo como a Idade Media e o século XIX, momentos en que o cancioneiro anónimo desenvolve un papel fundamental non só no nacemento dunha literatura culta no ámbito galego, senón tamén, e como é obvio, na configuración da lingua galega como medio de expresión desa literatura. Deste xeito, vimos como a literatura autóctona preexistente nos reinos occidentais da Península Ibérica se constituíu nun factor fundamental, xunto coa poesía provenzal, na xénese da literatura trobadoresca galego-portuguesa, unha das líricas máis sobranceiras da Europa medieval. De por parte, e despois de varias centurias en que a nosa literatura culta se viu sumida nun profundo silencio, é novamente a lírica tradicional

7 Véxase Freixeiro Mato / Sánchez Rei / Sanmartín Rei (2005: 692-716). 
un dos elementos que determinan, en maior ou menor medida, a renacenza das nosas letras, cuxo máximo expoñente é a aparición de Cantares gallegos, síntese perfecta entre a lírica de tradición oral e a criación literaria culta.

Por esta causa, xulgamos necesaria a realización dun breve estudo sobre o noso cancioneiro, as causas que motivaron a súa recuperación e recolleita no século XIX e algunhas das características lingüísticas que estas cántigas presentan, pezas que se constitúen nun testemuño inigualábel da fala popular ao longo dos tempos e nunha das máximas expresións da identidade do pobo galego.

\section{Referencias bibliográficas}

$A T=$ Tavani, G. (1999) (ed.): Arte de Trovar do Cancioneiro da Biblioteca Nacional (Lisboa: Colibri).

Blanco Pérez, D. (1997): "Literatura popular de tradición oral”, en VV.AA., Galicia. Vol. 28. Antropoloxía. Imaxinario. Literatura popular: 54-85 (A Coruña: Hércules de Ediciones).

Blanco Pérez, D. (2000) [1994]: Historia da literatura popular galega (Santiago de Compostela: Universidade de Santiago de Compostela).

Cohen, R. (2003): 500 Cantigas d'Amigo (Porto: Campo das Letras).

$D G C$ = Valladares, M. (1884): Diccionario Gallego-Castellano (Santiago de Compostela: Seminario Conciliar de Santiago).

Ferreiro, M. (1999) [1995]: Gramática histórica galega. Vol. I. Fonética e morfosintaxe (Santiago de Compostela: Laiovento).

Filgueira Valverde, X. (1990): Sexto Adral (A Coruña: Edicións do Castro).

Freixeiro Mato, X. R. (2003): “A lingua literaria decimonónica (II): aspectos gráficofónicos e morfosintácticos", en Tavares Maleval, M. do A. / Salinas Portugal, F. (coords.), Estudos Galego-Brasileiros: 79-111 (Rio de Janeiro: H. P. Comunicação).

Freixeiro Mato, X. R. / Sánchez Rei, X. M. / Sanmartín Rei, G. (2005): A lingua literaria galega no século XIX (A Coruña: Universidade da Coruña).

Lagares Díez, X. C. (2000): E por esto fez este cantar. Sobre as rubricas explicativas nos cancioneiros profanos galego-portugueses (Santiago de Compostela: Laiovento).

Lapa, M. Rodrigues (1995) [1965]: Cantigas d'escarnho e de mal dizer dos Cancioneiros Medievais Galego-Portugueses (Vigo: Ir Indo / Lisboa: Sá da Costa).

López, T. (1991): Névoas de antano. Ecos dos cancioneiros galego-portugueses no século XIX (Santiago de Compostela: Laiovento). 
Mariño Paz, R. (1999) [1998]: Historia da lingua galega (Santiago de Compostela: Sotelo Blanco).

Pérez Ballesteros, J. (ed.) (1979) [reprodución facsimilada da edición de 1886]: Cancioneiro popular gallego y en particular de la provincia de la Coruña por José Pérez Ballesteros. Tomo III (Madrid: Akal).

Saco Arce, J. A. (1987): "Introducción”, en Saco Cid, J. L. (ed.), Literatura popular de Galicia. Colección de coplas, villancicos, dialogos, romances, cuentos y refranes gallegos. Recogidos por: D. Juan Antonio Saco y Arce: 33-49 (Ourense: Diputación provincial de Ourense).

Sánchez Rei, X. M. (2003): “A lingua literaria decimonónica (III): aspectos do léxico”, en Tavares Maleval, M. do A. / Salinas Portugal, F. (coords.), Estudos GalegoBrasileiros: 113-160 (Rio de Janeiro: H. P. Comunicação).

Sánchez Rei, X. M. (2005): “Trazos xerais da tradición gramatical galega”, Revista galega de filoloxía, 6: 93-121.

Tavani, G. (1991) [1986]: A poesía lírica galego-portuguesa (Vigo: Galaxia).

Valladares, M. (1970) [redixida en 1892]: Elementos de gramática gallega (Vigo: Galaxia / Fundación Penzol).

Vasconcelos, C. Michaëlis de (1990) [reimp. da ed. de 1904, acrescentada de um prefácio de Ivo Castro e do glossário das cantigas (Revista Lusitana, XXIII)]: Cancioneiro da Ajuda, vol. II (Lisboa: Imprensa Nacional-Casa da Moeda).

Vilavedra, D. (coord.) (1995): Diccionario de literatura galega. Vol. I. Autores (Vigo: Galaxia). 